PENERAPAN MODEL PEMBELAJARAN TALKING STICK PADA MATA PELAJARAN FISIKA SISWA KELAS X SMA NEGERI SUKAKARYA

\author{
Ovilia Putri Utami Gumay, Andi Framanta
}

STKIP PGRI Lubuklinggau, Indonesia

\begin{abstract}
ABSTRAK
Tujuan penelitian ini adalah untuk mengetahui hasil belajar fisika siswa kelas $\mathrm{X}$ SMA Negeri Sukakarya setelah penerapan model Pembelajaran Talking Stick. Penelitian ini menggunakan metode kuasi eksperimen yang dilakukan dengan tidak adanya kelas pembanding. Berdasarkan Hasil observasi awal yang dilakukan peneliti di SMA Sukakarya diperoleh nilai rata-rata ulangan harian siswa kelas X hanya mencapai 67,65. Sedangkan Kriteria Ketuntasan Minimal yang ditetapkan sekolah yaitu 72. Populasi adalah semua siswa kelas X SMA Negeri Sukakarya yang berjumlah 60 siswa dan sampel kelas X.2 diambil secara acak. Berdasarkan hasil penelitian dapat disimpulkan bahwa rata-rata hasil belajar siswa sebesar 73,58 dan persentase jumlah siswa tuntas sebesar $61,54 \%$ dengan hasil uji-t dengan taraf kepercayaan $5 \%$ dan $\mathrm{dk}=\mathrm{n}-1$ didapat thitung $=0,68$ dan ttabel $=$ 1,708. Karena thitung $<$ ttabel maka hasil belajar fisika siswa kelas X SMA Negeri Sukakarya setelah diterapkan model Talking Stick tuntas namun tidak secara signifikan.
\end{abstract}

Kata Kunci: Model Pembelajaran Talking Stick, Hasil Belajar

\title{
PENDAHULUAN
}

Pendidikan merupakan bidang yang sangat penting, terutama bagi negaranegara berkembang seperti Indonesia. Berdasarkan Undang-Undang No. 20, Tahun 2003. Pasal 3, pendidikan nasional berfungsi mengembangkan kemampuan dan membentuk watak serta peradaban bangsa yang bermartabat dalam rangka mencerdaskan kehidupan bangsa, bertujuan untuk berkembangnya potensi peserta didik agar menjadi manusia yang beriman dan bertakwa kepada Tuhan Yang Maha Esa, berakhlak mulia, sehat, berilmu, cakap, kreatif, mandiri, dan menjadi warga negara yang demokratis serta bertanggung jawab.

http://ojs.stkippgri-lubuklinggau.ac.id/index.php/JPP 
Fisika merupakan ilmu pengetahuan yang mendasar, karena berhubungan dengan perilaku dan struktur benda, khususnya benda mati. Tujuan diajarkannya ilmu fisika adalah agar dapat mengetahui bagian-bagian dasar dari benda dan mengerti interaksi antara benda-benda, serta mampu menjelaskan mengenai fenomena-fenomena alam yang terjadi. Walaupun fisika terbagi atas beberapa bidang, hukum fisika berlaku universal.

Pembelajaran merupakan suatu proses yang kompleks, karena dalam kegiatan pembelajaran senantiasa mengintegrasikan berbagai komponen dan kegiatan, yaitu siswa dengan lingkungan belajar untuk memperoleh perubahan perilaku (hasil belajar) yang sesuai dengan tujuan. Dalam proses pembelajaran sebaiknya dilaksanakan dengan melibatkan mental siswa secara individu, bukan hanya menuntut siswa untuk mendengar dan mencatat penjelasan guru.

Berdasarkan hasil observasi awal yang dilakukan peneliti di SMA Sukakarya diperoleh nilai rata-rata ulangan harian siswa kelas $\mathrm{X}$ hanya mencapai 67,65. Sedangkan Kriteria Ketuntasan Minimal yang ditetapkan sekolah yaitu 72. Adapun siswa yang belum tuntas sebanyak 47 siswa $(78,33 \%)$ dan siswa yang tuntas 13 siswa $(21,66 \%)$ dari seluruh jumlah siswa kelas X yaitu sebanyak 60 siswa. Sehingga siswa yang belum tuntas harus mengikuti program remedial.

Hasil belajar yang rendah dapat diakibatkan karena siswa kurang aktif dalam proses belajar mengajar. Faktor kecil yang dapat mempengaruhi rendahnya hasil belajar siswa adalah karena pembelajaran yang disajikan masih dalam bentuk yang kurang menarik, sehingga terkesan sulit dipahami sehingga siswa tidak terlalu menguasai konsep dasar yang terkandung dalam materi pelajaran fisika. Hal tersebut dapat menghambat kreativitas siswa dalam menjawab soal, yang akhirnya hasil belajar siswa menjadi rendah. Faktor lain yang mengakibatkan kurang aktifnya siswa yaitu dikarenakan siswa tidak memiliki keberanian sehingga siswa takut untuk menyampaikan pendapat, selain itu adanya siswa yang sangat menonjol di kelas tersebut sehingga siswa lainnya merasa malu jika mendahului siswa yang mempunyai kemampuan lebih.

http://ojs.stkippgri-lubuklinggau.ac.id/index.php/JPP 
Masalah yang harus segera di atasi adalah hasil belajar siswa. Perubahan hasil belajar siswa tersebut akan memberi kemudahan dalam mengetahui sejauh mana perkembangan siswa dalam mengikuti proses belajar mengajar yang telah diterapkan kepada mereka. Untuk mengatasi masalah hasil belajar siswa, perlu diterapkannya model pembelajaran yang banyak melibatkan siswa sehingga siswa dapat lebih aktif. Salah satu model yang dapat digunakan untuk meningkatkan pembelajaran yaitu model pembelajaran Talking Stick. Oleh karena itu, tujuan penelitian ini adalah untuk mengetahui hasil belajar fisika siswa kelas X SMA Negeri Sukakarya setelah penerapan Model Pembelajaran Talking Stick.

\section{METODE PENELITIAN}

Jenis penelitian ini adalah penelitian eksperimen. Dalam hal ini metode eksperimen yang digunakan adalah eksperimen semu yaitu sebuah eksperimen yang dilaksanakan tanpa adanya kelas pembanding. Desain eksperimen yang akan digunakan berbentuk pre-test and post-test one group design. Teknik pengumpulan data yang dilakukan dalam penelitian ini adalah melalui teknik tes dengan soal berbentuk uraian.

\section{PEMBAHASAN}

\section{Kemampuan Awal Siswa (pre-test)}

Pemberian tes awal (pre-test) dilakukan untuk mengetahui kemampuan awal siswa sebelum diberikan perlakuan dengan model pembelajaran Talking Stick pada materi gerak lurus beraturan dan gerak lurus berubah beraturan. Rekapitulasi hasil tes awal siswa dapat dilihat pada Tabel 1. sebagai berikut:

http://ojs.stkippgri-lubuklinggau.ac.id/index.php/JPP 
Tabel 1. Rekapitulasi Data Tes Awal (Pretest)

\begin{tabular}{clc}
\hline No & \multicolumn{1}{c}{ Kategori } & Keterangan \\
\hline 1 & Nilai Minimum & 0 \\
2 & Nilai Maksimum & 39 \\
3 & Rata-rata Nilai & 20,85 \\
4 & Simpangan Baku & 10,42 \\
5 & Jumlah siswa yang tuntas & 0 orang $(0 \%)$ \\
\hline
\end{tabular}

Berdasarkan hasil penelitian data hasil tes awal pada Tabel 1 dapat dilihat bahwa tidak ada siswa yang mendapatkan nilai lebih atau sama dengan 72 (Tuntas). Rata-rata $(\bar{x})$ nilai secara keseluruhan sebesar 20,85. Jadi secara deskriptif dapat dikatakan bahwa kemampuan awal siswa sebelum penerapan model Talking Stick belum tuntas.

\section{Kemampuan Akhir Siswa (post-test)}

Pemberian tes akhir (postest) dilakukan untuk mengetahui kemampuan siswa setelah diberikan perlakuan dengan model pembelajaran Talking Stick pada materi gerak lurus beraturan dan gerak lurus berubah beraturan. Rekapitulasi hasil test akhir siswa disajikan pada Tabel 2. sebagai berikut:

Tabel 2 Rekapitulasi Data Tes Akhir (Post-Test)

\begin{tabular}{clc}
\hline No. & \multicolumn{1}{c}{ Kategori } & Keterangan \\
\hline $\mathbf{1}$ & Nilai Minimum & 50,00 \\
$\mathbf{2}$ & Nilai Maksimum & 91,30 \\
$\mathbf{3}$ & Rata-rata Nilai & 73,58 \\
$\mathbf{4}$ & Simpangan Baku & 10,42 \\
$\mathbf{5}$ & Jumlah siswa yang tuntas & 16 orang $(61,54 \%)$ \\
\hline
\end{tabular}

http://ojs.stkippgri-lubuklinggau.ac.id/index.php/JPP 
Berdasarkan hasil penelitian yang telah dilakukan, data hasil tes akhir pada Tabel 2 dapat dilihat bahwa siswa yang mendapatkan nilai lebih atau sama dengan 72 (Tuntas) di kelas X.2 sebanyak 16 siswa $(61,54 \%)$. Rata-rata $(\bar{x})$ nilai siswa secara keseluruhan sebesar 73,58. Jadi secara deskriptif dapat dikatakan bahwa kemampuan akhir siswa setelah pembelajaran dengan menerapkan model pembelajaran Talking Stick tuntas namun tidak signifikan.

\section{Uji Hipotesis}

Berdasarkan hasil uji coba normalitas ternyata data tes awal dan tes akhir berdistribusi normal. Karena simpangan baku populasi tidak diketahui dan data berdistribusi normal, Penarikkan kesimpulan dari data post-test, dapat dilakukan dengan pengujian hipotesis secara statistik, sehingga pengujian hipotesis sama dengan menggunakan uji-t dengan menggunakan rumus:

$$
t=\frac{\bar{x}-\mu o}{\frac{s}{\sqrt{n}}}
$$

Hipotesis yang diuji adalah :

$\mathrm{H}_{\mathrm{a}}: \mu>72$ : Rata-rata hasil belajar fisika siswa kelas X SMA Negeri Sukakarya Ciptodadi setelah diterapkan model Talking lebih besar dari 72 $\mathrm{H}_{0}: \mu \leq 72$ : Rata-rata hasil belajar fisika siswa kelas X SMA Negeri Sukakarya Ciptodadi setelah diterapkan model Talking Stick kurang dari sama dengan 72 .

Rekapitulasi hasil perhitungan uji normalitas dapat dilihat pada Tabel 3. sebagai berikut:

Tabel 3 Rekapitulasi Hasil Uji Hipotesis Data

\begin{tabular}{cccc}
\hline $\mathbf{t}_{\text {hitung }}$ & $\mathrm{dk}$ & $\mathbf{t}_{\text {tabel }}$ & Kesimpulan \\
\hline $\mathbf{0 , 6 8}$ & $5 \%$ & 1,708 & $\mathrm{H}_{0}$ diterima \\
\hline
\end{tabular}

http://ojs.stkippgri-lubuklinggau.ac.id/index.php/JPP 
Berdasarkan Tabel 3 menunjukkan nilai $\mathrm{t}_{\text {hitung }}<\mathrm{t}_{\text {tabel, }}$ hal ini berarti $\mathrm{H}_{0}$ diterima dan $\mathrm{H}_{\mathrm{a}}$ ditolak. Dengan kata lain hipotesis yang diajukan dalam penelitian ini tidak dapat diterima kebenarannya, artinya "Hasil belajar fisika siswa di kelas X SMA Negeri Sukakarya setelah diterapkan model pembelajaran Talking Stick tuntas namun tidak secara signifikan”.

\section{Pembahasan}

Berdasarkan pada rumusan masalah yang akan dikemukakan dalam penelitian ini adalah "Apakah dengan Menerapkan Model Pembelajaran Talking Stick, hasil belajar fisika di kelas X SMA Negeri Sukakarya secara signifikan tuntas?". Berdasarkan analisis data pre-test dapat dilihat bahwa tidak ada siswa yang mendapatkan nilai lebih dari 72 (tuntas). Rata-rata nilai siswa secara keseluruhan 20,85, jadi dapat disimpulkan hasil pre-test sebelum diterapkan model Talking Stick belum tuntas. Setelah dilakukannya tes awal, peneliti melakukan pembelajaran dengan penerapan model Talking Stick. Pembelajaran dilakukan sebanyak tiga kali pertemuan.

Pada pertemuan pertama, sebelum pembelajaran dimulai guru menyiapkan sebuah tongkat dan kemudian guru menjelaskan materi pokok kepada siswa. Setelah itu guru menuliskan pertanyaan di papan tulis dan memberikan waktu kepada siswa mempelajari materi yang telah dijelaskan. Jika siswa telah selesai mempelajari materi tersebut dengan batas waktu yang telah ditentukan barulah menerapkan pembelajaran dengan menggunakan model Talking Stick. Pada saat penerapan model hanya sebagian siswa yang mengerti mengenai model Talking Stick ini dan sebagian lainnya masih bingung. Pada saat tongkat bergulir dari siswa satu ke siswa yang lain mereka dengan cepat memberikan tongkat tersebut kepada yang lainnya karena siswa tersebut takut untuk mengerjakan soal ke depan dan belum terbiasa dalam menerapkan model. Pada pertemuan kedua, guru kembali menyiapkan tongkat dan menjelaskan materi pokok. Pertemuan kedua ini seluruh siswa mulai memahami bagaimana belajar dengan menggunakan model http://ojs.stkippgri-lubuklinggau.ac.id/index.php/JPP 
pembelajaran. Siswa tidak lagi dengan cepat melemparkan tongkat tersebut kepada siswa yang lainnya. Siswa juga sudah lebih siap jika mereka mendapat giliran untuk mengerjakan soal di depan kelas dibandingkan pada saat pertemuan pertama.

Pertemuan ketiga guru kembali menyiapkan tongkat dan menjelaskan materi pokok. Dalam pertemuan ketiga ini siswa sangat menikmati proses pembelajaran. Siswa sangat senang dan termotivasi untuk belajar karena belajar dengan mendengarkan musik dan menciptakan suasana belajar sambil bermain sehingga siswa tidak merasa bosan.

Menurut Suprijono (2009:109), "Pembelajaran dengan model Talking Stick mendorong peserta didik untuk berani mengungkapkan pendapat". Sedangkan Muawanah (2014:58) menyatakan bahwa model Talking Stick adalah model pembelajaran dengan menggunakan bantuan tongkat, siswa yang memegang tongkat wajib menjawab pertanyaan dari guru setelah siswa mempelajari materi pokoknya.

Setelah melakukan pembelajaran dengan menerapkan model Talking Stick, siswa diberikan tes akhir. Berdasarkan hasil perhitungan Post-test diadakan setelah penyampaian materi dengan model Talking Stick, dalam hal ini dapat dilihat bahwa 16 siswa yang mendapatkan nilai lebih dari 72. Rata-rata nilai siswa secara keseluruhan 73,57. Berdasarkan pengujian hipotesis dapat disimpulkan bahwa "Hasil Belajar Fisika Siswa Kelas X MA SMA Ciptodadi Sukakarya Musi Rawas Setelah Diterapkan Model Talking Stick Tuntas Namun Tidak Signifikan”.

Hasil belajar yang tuntas namun tidak secara signifikan tersebut disebabkan karena siswa masih memiliki rasa takut untuk mengerjakan soal yang diberikan sehingga menyebabkan siswa belum memiliki kreativitas dalam menjawab soal tersebut. Selain itu juga, masih banyak siswa yang kurang bisa untuk memahami materi yang dipelajari sehingga pengetahuan tentang materi tersebut masih lemah.

http://ojs.stkippgri-lubuklinggau.ac.id/index.php/JPP 


\section{KESIMPULAN}

Berdasarkan hasil penelitian dan pembahasan dapat disimpulkan bahwa rata-rata hasil belajar siswa sebesar 73,58 dan persentase jumlah siswa tuntas sebesar 61,54\% dengan hasil uji-t dengan taraf kepercayaan 5\% dan $\mathrm{dk}=\mathrm{n}-1$ didapat $t_{\text {hitung }}=0,68$ dan $t_{\text {tabel }}=1,708$. Karena $t_{\text {hitung }}<t_{\text {tabel }}$ maka hasil belajar fisika siswa kelas X SMA Negeri Sukakarya setelah diterapkan model Talking Stick tuntas namun tidak secara signifikan.

\section{DAFTAR PUSTAKA}

Arikunto, S. 2010. Prosedur Peneltian Suatu Pendekatan Praktek. Jakarta: Rieneka Cipta.

Dimyati \& Mudjiono. 2009. Belajar dan Pembelajaran. Jakarta: Rieneka Cipta.

Hamalik, O. 2008. Proses Belajar Mengajar. Jakarta: Bumi Aksara.

Muawanah. 2014. Penerapan Model Talking Stick Dengan Media Visual Dalam Pembelajaran IPS Materi Perkembangan Teknologi. Jurnal Penelitian Tindakan Kelas. 2 (16), 58-66.

Purwanto, 2011. Statistika Untuk Penelitian. Yogyakarta: Pustaka Pelajar.

Rusman. 2010. Model-Model Pembelajaran Mengembangkan Profesionalisme Guru. Jakarta: Raja Grafindo Persada.

Sugiyono. 2013. Statistika Untuk Penelitian. Bandung: Alfabeta.

Suprijono, Agus. 2013. Cooperatif Learning Teori \& Aplikasi PAIKEM. Yogyakarta: Pustaka Pelajar.

Trianto. 2011. Model Pembelajaran Terpadu. Jakarta: PT. Bumi Aksara

http://ojs.stkippgri-lubuklinggau.ac.id/index.php/JPP 